\title{
Gambaran Ketajaman Penglihatan terhadap Lama Penggunaan dan Jarak Pandang Gadget pada Siswa Kelas XII SMA Negeri 9 Binsus Manado
}

\author{
${ }^{1}$ Randy Richter \\ ${ }^{2}$ Laya M. Rares \\ ${ }^{2}$ Imelda H. M. Najoan
}

\author{
${ }^{1}$ Program Studi Pendidikan Dokter Fakultas Kedokteran Universitas Sam Ratulangi Manado \\ ${ }^{2}$ Bagian Ilmu Kesehatan Mata Fakultas Kedokteran Universitas Sam Ratulangi Manado \\ Email: randyrichter13@yahoo.com
}

\begin{abstract}
Deterioration of visual acuity commonly occurs among students. This study was aimed to obtain the profile of visual acuity related to duration of gadget usage and distance between eye and the gadget among XII grade students of SMA Negeri 9 Binsus Manado (senior high school). This was a descriptive study. There were 105 students as subjects in this study; 34 of them (32.38\%) had decreased visual acuity. There were 80 subjects $(76.19 \%)$ that did not wear glasses, consisted of 27 males $(25.72 \%)$ and 44 females (41.9\%). Gadget usage for $\geq 2$ hours was found in 99 subjects $(94.29 \%)$. The most common visual length of using gadget was $<30 \mathrm{~cm}$ which was found in 85 subjects $(80.95 \%)$. At day-30, visual acuity examination did not reveal any significant improvement. Conclusion: In this study, most students had normal visus and the majority were females and age of 17 years. Most students used gadget for $\geq 2$ hours, and the visual length of using gadget was $<30 \mathrm{~cm}$. There was no significant improvement of visual acuity after 30 days.
\end{abstract}

Keywords: visual acuity, glasses, gadget

\begin{abstract}
Abstrak: Penurunan tingkat ketajaman penglihatan pada kalangan usia sekolah merupakan salah satu masalah yang paling sering terjadi. Penelitian ini bertujuan untuk mendapatkan gambaran ketajaman penglihatan terhadap lama penggunaan dan jarak pandang gadget pada siswa kelas XII SMA Negeri 9 Binsus Manado. Jenis penelitian ialah deskriptif retrospektif. Hasil penelitian mendapatkan 105 siswa kelas XII SMA Negeri 9 Binsus sebagai subyek penelitian. Jumlah subyek yang mengalami penurunan visus ialah 34 siswa $(32,38 \%)$. Siswa yang tidak memakai kacamata lebih banyak dibandingkan yang memakai kacamata dengan jumlah 80 siswa (76,19\%), terdiri dari 27 laki-laki (25,72\%) dan 44 perempuan (41,9\%). Kasus lama penggunaan gadget yang terbanyak ialah $\geq 2$ jam dengan jumlah 99 siswa $(94,29 \%)$. Jarak pandang gadget yang terbanyak ialah $<30 \mathrm{~cm}$ dengan jumlah 85 siswa $(80,95 \%)$. Pada hari ke-30 penelitian, pemeriksaan ketajaman penglihatan tidak mendapatkan perubahan visus yang nyata. Simpulan: Sebagian besar siswa memiliki visus normal, didominasi oleh jenis kelamin perempuan dan usia 17 tahun. Umumnya lama penggunaan gadget $\geq 2$ jam dengan jarak pandang gadget $<30 \mathrm{~cm}$. Tidak didapatkan perubahan visus yang nyata setelah 30 hari.
\end{abstract}

Kata kunci: ketajaman penglihatan, kacamata, gadget

Mata adalah salah satu organ yang sangat kompleks, terdiri dari berbagai struktur yang saling bekerja sama untuk memberikan suatu indera penglihatan. ${ }^{1}$ Mata merupakan organ yang sangat penting dan berfungsi dalam menganalisis secara cermat dari sebuah bentuk, intensitas cahaya, serta warna yang dipantulkan oleh 
suatu objek yang akan digunakan untuk mengumpulkan, memroses, atau memberikan informasi visual dalam melakukan berbagai aktivitas sehari-hari. ${ }^{2}$ Gangguan terhadap kualitas ketajaman penglihatan sering terjadi khususnya berkaitan dengan lama penggunaan gadget serta jarak pandang terhadap gadget.

Penggunaan gadget saat ini bukan hanya sebagai alat komunikasi, namun gadget juga bisa dipakai dalam berbagai hal seperti media sosial, bermain game atau, hal serupa yang membuat aktivitas dengan gadget semakin lama. ${ }^{4}$ Tampilan tulisan pada layar gadget saat ini ukurannya lebih kecil daripada tulisan yang tertera pada buku. Hal ini membuat para pengguna gadget membaca tulisan dalam jarak yang cukup dekat, sehingga dapat menimbulkan gejala-gejala gangguan pada penglihatan seperti mata lelah, penglihatan buram, penglihatan ganda, pusing, mata kering serta ketidaknyamanan pada mata saat melihat sesuatu objek baik dekat atau jauh. ${ }^{3}$

Ketajaman penglihatan atau visus adalah suatu kemampuan mata dalam membedakan bagian-bagian yang sangat spesifik baik objek atau suatu permukaan. Kelainan pada ketajaman penglihatan merupakan gejala yang paling umum dikeluhkan oleh orang yang mengalami gangguan penglihatan. Pada anak usia sekolah, hal ini merupakan salah satu masalah yang paling sering terjadi terhadap tingkat ketajaman penglihatan. ${ }^{5}$

Menurut data dari World Health Organization (WHO) diperkirakan pada tahun 2000 terdapat 45 juta penderita kebutaan di dunia; sepertiga bagiannya terletak di Asia Tenggara. Berdasarkan hasil survei kesehatan rumah tangga tahun 2001, angka kebutaan di Indonesia menurun menjadi $1,2 \%$ tetapi angka ini masih lebih tinggi dibandingkan tiga negara lainnya yaitu Bangladesh $(1,0 \%)$, India $(0,7 \%)$, dan Thailand $(0,3 \%){ }^{6}$

Penelitian yang dilakukan pada tahun 2010 menunjukkan bahwa kelompok yang paling sering menggunakan gadget yakni anak sekolah dengan rata-rata penggunaan gadget lebih dari tujuh jam. Pemakaian gadget yang berlebihan didefinisikan pada mereka yang menggunakan gadget lebih dari dua jam per hari.

Data statistik yang dilakukan terhadap aktivitas penggunaan gadget di Indonesia pada tahun 2018 melaporkan sekitar 100 juta pengguna aktif gadget atau terjadi peningkatan sebesar $20 \%$ dari tahun sebelumnya dengan angka pengguna aktif gadget sebanyak 86,6 juta pengguna. Data statistik ini menjadikan Indonesia sebagai populasi pengguna gadget terbesar keempat setelah China, India dan Amerika Serikat. ${ }^{8}$

Penelitian ini bertujuan untuk mendapatkan gambaran ketajaman penglihatan terhadap lama penggunaan dan jarak penggunaan gadget pada siswa kelas XII SMA Negeri 9 Binsus Manado.

\section{METODE PENELITIAN}

Jenis penelitian ini ialah deskriptif dengan metode purposive sampling. Dilakukan pengukuran visus dan pengisian kuesioner di SMA Negeri 9 Binsus Manado. Subyek penelitian ini ialah semua siswa-siswi kelas XII IPA SMA Negeri 9 Binsus Manado. Variabel penelitian yang diteliti yaitu ketajaman penglihatan, lama penggunaan gadget, dan jarak pandang gadget.

Penelitian ini melibatkan 105 subyek penelitian yang dilakukan dua kali yakni hari pertama dan hari ke-30. Diteliti ketajaman penglihatan terhadap lama penggunaan dan jarak pandang gadget dalam satu bulan terakhir. Setelah mendapatkan persetujuan dari subyek, peneliti mengambil data dan mengadakan pemeriksaan dengan autorefraktometer dan Snellen chart.

\section{HASIL PENELITIAN}

Tabel 1 menunjukkan bahwa siswa dengan visus normal lebih banyak dibandingkan siswa dengan visus menurun, yaitu sebanyak 71 siswa $(67,62 \%)$. Siswa dengan jenis kelamin perempuan lebih banyak memiliki visus normal yaitu sebanyak 44 siswa $(41,9 \%)$. Siswa dengan jenis kelamin laki-laki lebih banyak memiliki visus normal yaitu sebanyak 27 siswa $(25,72 \%)$. 
Tabel 1. Distribusi tajam penglihatan berdasarkan jenis kelamin $(n=105)$

\begin{tabular}{ccccc}
\hline & \multicolumn{4}{c}{ Visus } \\
\hline \multirow{2}{*}{ Jenis } & \multicolumn{2}{c}{ Normal } & \multicolumn{2}{c}{ Menurun } \\
\cline { 2 - 5 } kelamin & n & \% & n & $\%$ \\
\hline Laki-Laki & 27 & 25,72 & 11 & 10,48 \\
Perempuan & 44 & 41,9 & 23 & 21,9 \\
Total & 71 & 67,62 & 34 & 32,38 \\
\hline
\end{tabular}

Tabel 2 menunjukkan bahwa usia 17 tahun paling banyak pada siswa SMA Negeri 9 Binsus Manado kelas XII IPA dengan jumlah 56 siswa $(53,33 \%)$. Subyek dengan visus normal paling banyak berada pada usia 17 tahun yaitu 37 siswa $(35,24 \%)$ dan pada visus menurun paling banyak berada pada usia 17 tahun juga yaitu 19 siswa $(18,1 \%)$.

Gambar 1 menunjukkan bahwa jumlah siswa SMA Negeri 9 Binsus Manado kelas XII IPA yang tidak memakai kacamata lebih banyak dibandingkan yang memakai kacamata yaitu 80 siswa $(76,19 \%)$. Siswa yang tidak memakai kacamata paling banyak pada usia 17 tahun dengan jumlah 42 siswa (40\%). Jenis kelamin yang paling banyak tidak memakai kacamata yaitu jenis kelamin perempuan dengan usia 16 tahun yaitu 24 siswa $(22,86 \%)$. Untuk yang memakai kacamata, jenis kelamin terbanyak yaitu perempuan dengan jumlah 18 siswa $(17,14 \%)$ dan usia yang terbanyak memakai kacamata yaitu 17 tahun dengan jumlah 14 siswa $(13,33 \%)$.

Tabel 2. Distribusi tajam penglihatan berdasarkan usia $(\mathrm{n}=105)$

\begin{tabular}{ccccc}
\hline \multirow{2}{*}{$\begin{array}{c}\text { Usia } \\
\text { tahun) }\end{array}$} & \multicolumn{4}{c}{ Visus } \\
\cline { 2 - 5 } & $\mathbf{n}$ & $\%$ & $\mathbf{n}$ & $\%$ \\
\hline 15 & 2 & 1,9 & 2 & 1,9 \\
16 & 32 & 30,48 & 12 & 11,43 \\
17 & 37 & 35,24 & 19 & 18,1 \\
18 & 0 & 0 & 1 & 0,95 \\
Total & 71 & 67,62 & 34 & 32,38 \\
\hline
\end{tabular}

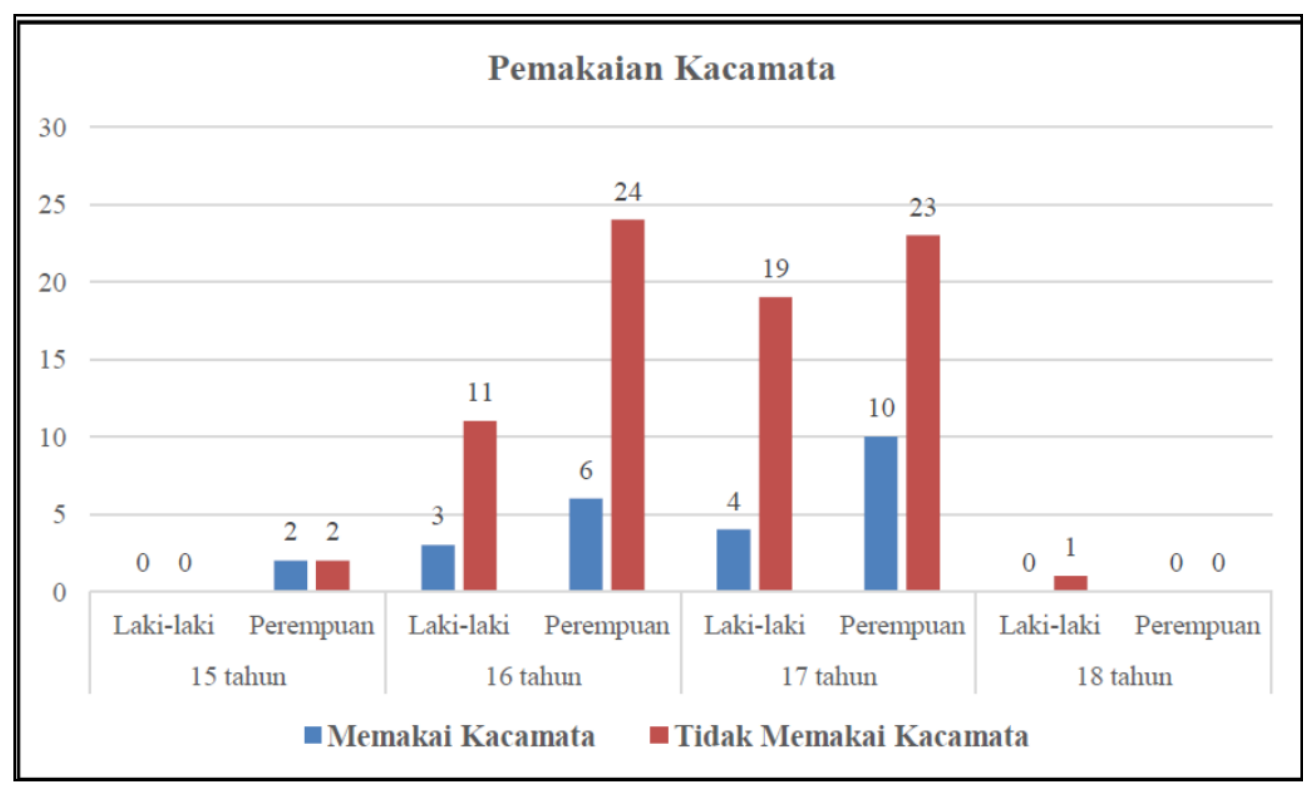

Gambar 1. Distribusi pemakaian kacamata berdasarkan jenis kelamin dan usia $(n=105)$

Gambar 2 menunjukkan bahwa selama satu bulan penelitian, jumlah siswa dengan penurunan visus lebih sedikit dibandingkan denngan yang tidak ada penurunan visus yaitu 13 siswa (12\%).

Gambar 3 menunjukkan bahwa lama penggunaan gadget pada siswa SMA Negeri 9 Binsus Manado kelas XII IPA paling banyak yaitu $\geq 2$ jam. Jenis kelamin yang paling banyak menggunakan gadget dengan lama penggunaan $\geq 2$ jam yaitu jenis kelamin perempuan dengan jumlah 63 
siswa (60\%), sedangkan jenis kelamin yang paling sedikit menggunakan gadget dengan lama penggunaan $<2$ jam yaitu jenis kelamin laki-laki dengan jumlah dua siswa $(1,9 \%)$.

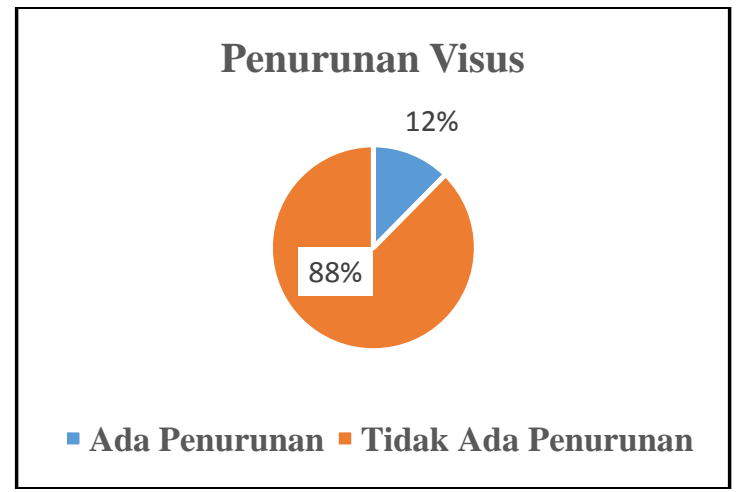

Gambar 2. Karakteristik responden menurut perubahan ketajaman penglihatan selama satu bulan $(\mathrm{n}=105)$

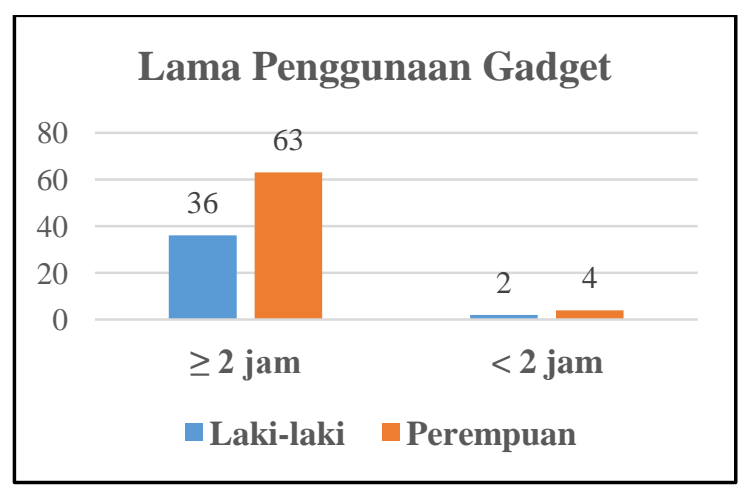

Gambar 3. Distribusi lama penggunaan gadget berdasarkan jenis kelamin

Gambar 4 menunjukkan bahwa lama penggunaan gadget pada siswa SMA Negeri 9 Binsus Manado kelas XII IPA paling banyak yaitu $\geq 2$ jam. Jenis kelamin yang paling banyak menggunakan gadget dengan lama $\geq 2$ jam yaitu jenis kelamin perempuan dengan jumlah 63 siswa (60\%), sedangkan jenis kelamin yang paling sedikit menggunakan gadget dengan lama penggunaan $<2$ jam yaitu jenis kelamin laki-laki dengan jumlah dua siswa $(1,9 \%)$.

Gambar 5 menunjukkan bahwa lama penggunaan gadget terhadap siswa SMA Negeri 9 Binsus Manado kelas XII IPA lebih banyak $\geq 2$ jam pada usia 17 tahun yaitu dengan jumlah 53 siswa $(50,48 \%)$ dan paling sedikit pada usia 18 tahun yaitu satu siswa $(0,95 \%)$. Untuk lama penggunaan $<2$ jam paling banyak pada usia 17 tahun dengan jumlah tiga siswa $(2,86 \%)$ dan paling sedikit pada usia 15 tahun yaitu satu siswa $(0,95 \%)$.

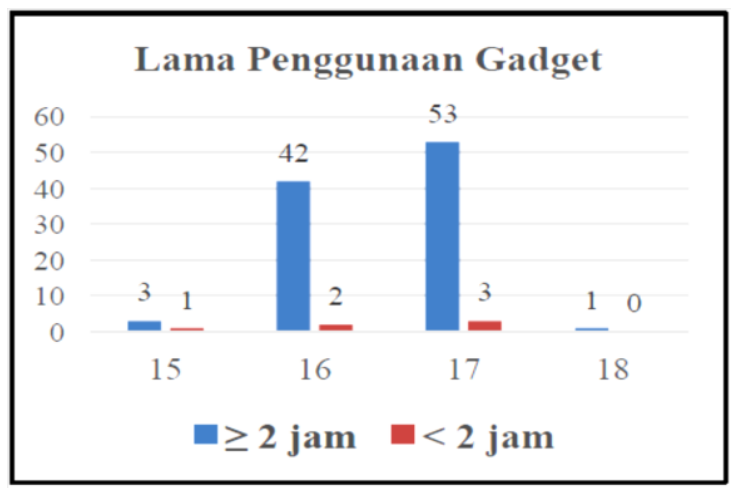

Gambar 4. Distribusi lama penggunaan gadget berdasarkan usia $(\mathrm{n}=105)$

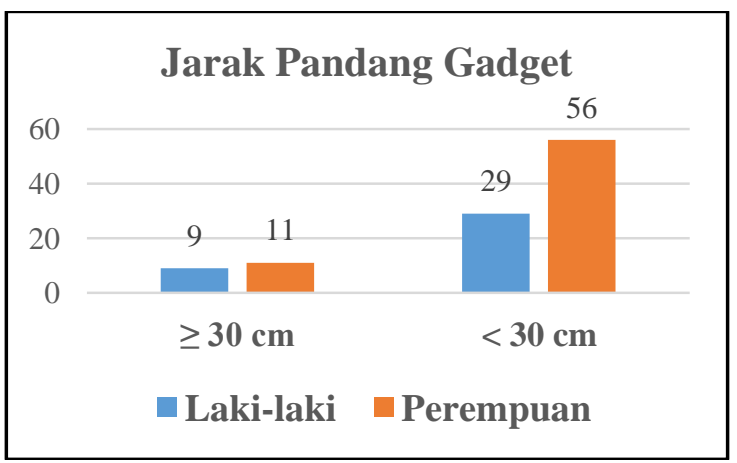

Gambar 5. Distribusi jarak pandang gadget berdasarkan jenis kelamin $(n=105)$

Gambar 6 menunjukkan bahwa jarak pandang gadget terhadap siswa SMA Negeri 9 Binsus Manado kelas XII IPA paling banyak yaitu $<30 \mathrm{~cm}$ Jenis kelamin yang paling banyak menggunakan gadget dengan jarak pandang $<30 \mathrm{~cm}$ yaitu perempuan dengan jumlah 56 siswa $(53,33 \%)$, sedangkan jenis kelamin yang paling sedikit menggunakan gadget dengan jarak pandang $\geq 30 \mathrm{~cm}$ yaitu jenis kelamin lakilaki dengan jumlah 9 siswa $(8,57 \%)$.

\section{BAHASAN}

Penelitian yang dilakukan secara deskriptif retrospektif di SMA Negeri 9 Binsus Manado terhadap siswa yang mengalami penurunan ketajaman penglihatan terhadap gadget yang diambil dengan metode peng- 


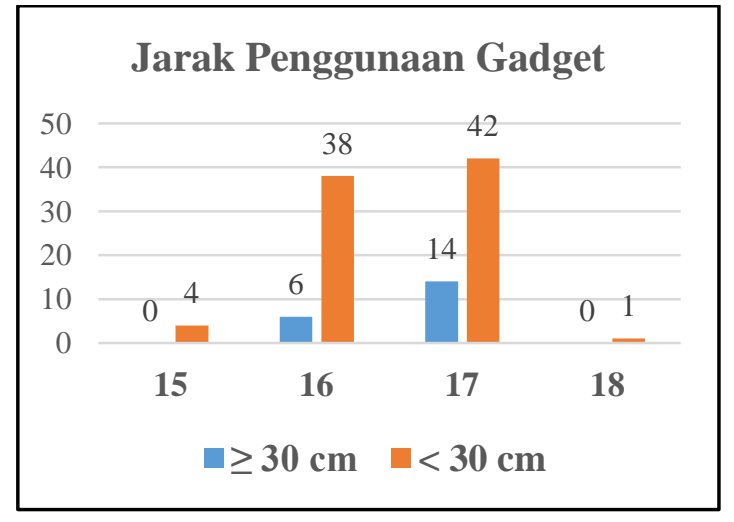

Gambar 6. Distribusi jarak pandang gadget berdasarkan usia $(\mathrm{n}=105)$

ambilan sampel purposive sampling. Didapatkan 105 siswa yang menjadi subyek penelitian dan telah memenuhi kriteria inklusi termasuk tidak menggunakan lensa kontak atau alat bantu penglihatan. Hasil penelitian ini mendapatkan subyek dengan visus normal lebih dominan dibandingkan yang dengan penurunan visus yaitu 71 siswa $(67,62 \%)$. Hasil tersebut sejalan dengan penelitian oleh Ernawati ${ }^{9}$ yang melaporkan bahwa visus normal lebih dominan yaitu 31 anak $(56,4 \%)$.

Distribusi tajam penglihatan berdasarkan jenis kelamin menunjukkan bahwa sebagian besar subyek berjenis kelamin perempuan yaitu 67 siswa $(63,81 \%)$. Hal ini didukung oleh penelitian yang dilakukan Handriani ${ }^{10}$ yang mendapatkan jenis kelamin perempuan lebih banyak yaitu 40 responden $(62,5 \%)$. Bawelle ${ }^{11}$ juga melaporkan hasil serupa yaitu jenis kelamin perempuan lebih banyak yaitu 36 responden $(72 \%)$. Hasil ini berbeda dengan penelitian yang dilakukan oleh Dalope, ${ }^{12}$ yang melaporkan bahwa jenis kelamin lakilaki yang lebih banyak yaitu 45 responden $(73,77 \%)$. Hal tersebut disebabkan karena jumlah responden laki-laki pada penelitian itu lebih banyak dibandingkan jumlah responden perempuan.

Distribusi tajam penglihatan berdasarkan usia menunjukkan bahwa yang terbanyak yaitu usia 17 tahun untuk tajam penglihatan dengan nilai visus normal sebanyak 37 siswa $(35,24 \%)$. Hal ini sejalan dengan penelitian yang dilakukan Adile $^{13}$ yang melaporkan bahwa usia 17 tahun yang terbanyak yaitu 13 responden (52\%). Daya akomodasi mata akan semakin menurun seiring bertambahnya usia. ${ }^{14-}$ 15 Hal serupa juga dikemukakan oleh Gabriel, ${ }^{16}$ yang menyatakan bahwa usia merupakan salah satu faktor dalam hal kemampuan lensa mata untuk memfokuskan suatu objek.

Hasil pemeriksaan tajam penglihatan menunjukkan bahwa siswa yang tidak memakai kacamata lebih dominan dibandingkan yang memakai kacamata yaitu 80 siswa $(76,19 \%)$. Hal ini didukung oleh penelitian yang dilakukan oleh Fitri, ${ }^{17}$ dimana responden lebih dominan yang tidak memakai kacamata yaitu 95 orang (96,9\%). Penelitian yang dilakukan oleh Hutami et al. ${ }^{18}$ menyatakan bahwa keluarga yang paling dominan yaitu yang tidak menggunakan kacamata dengan jumlah 73 responden $(72,3 \%)$ yang mengalami penurunan visus serta 28 responden $(27,7 \%)$ yang mengalami tajam penglihatan dengan nilai visus normal.

Hasil pemeriksaan lama penggunaan gadget terhadap tajam penglihatan mendapatkan bahwa jenis kelamin yang paling banyak menggunakan gadget dengan lama $\geq 2$ jam yaitu jenis kelamin perempuan dengan jumlah 63 siswa $(60 \%)$. Subyek berusia 17 tahun paling banyak menggunakan gadget dengan lama $\geq 2$ jam berjumlah 53 siswa $(50,48 \%)$. Hal ini serupa dengan penelitian yang dilakukan di Jamaica oleh Mowatt et al. ${ }^{19}$ yang mendapatkan bahwa pengguna gadget dengan lama $\geq 2$ jam lebih banyak yaitu 380 responden $(92,9 \%)$ dan lebih khusus paling banyak dengan lama penggunaan $>6$ jam yaitu 165 responden (40,3\%). Hasil penelitian tersebut didukung juga oleh penelitian yang dilakukan oleh Navarona, ${ }^{20}$ yang mendapatkan lama penggunaan gadget dengan lama $\geq 2$ jam paling banyak yaitu 44 responden $(68,8 \%)$. Hasil penelitian ini selaras dengan penelitian Ernawati yang mendapatkan frekuensi lama menggunakan gadget yang berlebihan lebih banyak dibandingkan yang normal yaitu 30 responden (54,5\%). ${ }^{9,19,20}$ Rosenfield dari The State University of New York College of Optometry mengemukakan bahwa sese- 
orang yang terlalu lama membaca sesuatu lewat gadget (smartphone, tablet, atau laptop) akan membuat keluhan subyektif seperti mata terasa kering. Akibatnya keluh-an subyektif yang paling banyak akan muncul yaitu sulit melihat jarak jauh dan mengalami kelelahan mata sebanyak 29 responden $(45,3 \%))^{3,21}$ Menurut penelitian di Sri Lanka oleh Thilakarathne et al. ${ }^{22}$ gejala yang paling sering yaitu sakit kepala dan didominasi oleh jenis kelamin perempuan sebesar $61,5 \% .^{20,22}$

Hasil pemeriksaan jarak pandang gadget terhadap tajam penglihatan menunjukkan bahwa jenis kelamin yang paling banyak menggunakan gadget dengan jarak pandang $<30 \mathrm{~cm}$ yaitu jenis kelamin perempuan berjumlah 56 siswa $(53,33 \%)$ dan yang berusia 17 tahun berjumlah 42 siswa (40\%). Hal ini didukung dengan penelitian yang dilakukan oleh Navarona, yang menyatakan bahwa jarak pandang gadget paling banyak didapatkan dengan jarak pandang $<30 \mathrm{~cm}$ yaitu pada 36 responden $(56,2 \%)$. Penelitian serupa juga dilakukan oleh Thilakarathne et al. ${ }^{22}$ mendapatkan bahwa jarak pandang terhadap gadget dalam hal ini jarak ke layar monitor lebih banyak $<20 \mathrm{~cm}$ sebanyak 69 responden $(61,6 \%)$. Menurut penelitian di Korea oleh Kim et al. ${ }^{23}$ penggunaan gadget dengan jarak pandang yang dekat dalam jangka waktu lama dapat menimbulkan gejala subyektif yang paling sering yaitu asthenopia (mata lelah). Penelitian di Nepal oleh Dhungel dan Shrestha ${ }^{24}$ mendapatkan bahwa pada 112 responden yang diteliti penggunaan gadget dengan jarak pandang dekat pada kelompok umur 16-20 tahun, gejala internal yang paling sering yaitu pandangan kabur, dan gejala eksternal yang paling sering yaitu mata rasa terbakar.

\section{SIMPULAN}

Berdasarkan hasil penelitian ini dapat disimpulkan bahwa sebagian besar siswa memiliki visus normal, didominasi oleh jenis kelamin perempuan dan usia 17 tahun. Umumnya lama penggunaan gadget $\geq 2$ jam dengan jarak pandang gadget $<30 \mathrm{~cm}$. Tidak didapatkan perubahan visus yang nyata setelah 30 hari.

Dari hasil penelitian dapat disimpulkan bahwa 32,38\% dari responden yang dilakukan pengukuran visus mengalami penurunan visus, kasus tertinggi didapatkan pada jenis kelamin perempuan dan pada usia 17 tahun. Siswa yang tidak memakai kacamata lebih dominan yakni 76,19\% dimana dalam satu bulan tidak ada perubahan signifikan terhadap visus. Lama penggunaan gadget tertinggi yaitu $\geq 2$ jam sebesar 94,29\% dan jarak pandang gadget tertinggi yaitu $<30 \mathrm{~cm}$ sebesar $80,95 \%$.

\section{SARAN}

Para siswa diharapkan dapat meningkatkan pengetahuan tentang pentingnya fungsi penglihatan untuk menghindari faktor-faktor resiko sebagai pencegahan terhadap penurunan ketajaman penglihatan.

Disarankan untuk melakukan penelitian dalam jangka waktu yang lama, cakupan sampel yang lebih luas yaitu sampai ke kelas $\mathrm{X}$ dan kelas XI, bisa meneliti tentang tingkat intensitas cahaya dan posisi saat menggunakan gadget pada kalangan sekolah menengah atas dan bisa menjadi acuan untuk penelitian selanjutnya.

Ucapan terima kasih ditujukan kepada seluruh siswa dan guru SMA Negeri 9 Binsus Manado atas partisipasinya dan Staf refraksionis Bagian Ilmu Kesehatan Mata atas bantuan dan kerja samanya serta pihak lain yang terlibat dalam penyelesaian penelitian ini.

\section{DAFTAR PUSTAKA}

1. Carolyn S. Anatomy and Physiology of the Eye. BSM Consulting, 2012; p 3.

2. Junquiera LC, Carneiro J, Kelley RO. Histologi dasar (5th ed). Terjemahan dari Basic Histology. Jakarta: EGC, 2007.

3. Rosenfield M. Computer vision syndrome: a review of ocular causes and potential treatments. Ophthalmic Physiol Optic. 2011;31(5):502-15.

4. Manumpil B, Ismanto AY, Onibala F. Hubungan penggunaan gadget dengan 
tingkat prestasi siswa di SMA Negeri 9

Manado. Jurnal Keperawatan; 2015; 3(2):1-6.

5. Hartono. Simptomalogi dalam Neuro-oftalmologi. Yogyakarta: Pustaka Cendekia Press, 2009.

6. Depkes RI. Gangguan penglihatan masih menjadi masalah kesehatan. 2009. Availabe from: http://www.depkes. go.id/index.php/berita/press-release/ 845-gangguan-penglihatan-masihmenjadi-masalah-kesehatan.

7. American Optometric Association. Impact of computer use on children's vision. Available from: https://www.aoa.org/ optometrists/tools-and-resources/ clinical-care-publications/ environmental/occupationalvision/computer-use-needs/impact-ofcomputer-use-on-childrens-vision

8. Kementerian Komunikasi dan Informatika Republik Indonesia. Indonesia raksasa teknologi digital Asia. 2018. Available from:https://www.kominfo.go.id/conte nt/detail/6095/indonesia-raksasateknologi-digital-asia/0/sorotan_media

9. Ernawati W. Pengaruh penggunaan gadget terhadap penurunan tajam penglihatan pada anak usia sekolah (6-12 tahun) di SD Muhammadiyah 2 Pontianak Selatan. Jurnal ProNers. 2015;3(1).

10. Handriani M. Pengaruh unsafe action penggunaan gadget terhadap ketajaman penglihatan siswa Sekolah Dasar Islam Tunas Harapan [Skripsi]. Tidak dipublikasikan. Semarang: Universitas Dian Nuswantoro; 2016.

11. Bawelle CFN. Hubungan penggunaan smartphone dengan fungsi penglihatan pada mahasiswa Fakultas Kedokteran Universitas Sam Ratulangi Manado angkatan 2016. Manado: Universitas Sam Ratulangi; 2016.

12. Dalope JML. Prevalensi penurunan visus pada siswa berkebutuhan khusus di SLB Kasih Angelia Kota Bitung tahun ajaran 2017/2018 [Skripsi]. Manado: Universitas Sam Ratulangi; 2017.

13. Adile AV. Kelainan refraksi pada pelajar SMA Negeri 7 Manado [Skripsi]. Manado: Universitas Sam Ratulangi; 2016.

14. Ilyas HS, Yulianti SR. Ilmu Penyakit Mata. (5th ed). Jakarta: Fakultas Kedokteran Universitas Indonesia, 2015.

15. Ilyas S. Kelainan Refraksi dan Kacamata. Jakarta: Fakultas Kedokteran Universitas Indonesia, 2006.

16. Gabriel JF. Fisika Kedokteran. Jakarta: EGC, 2013; p.140-200.

17. Fitri TI. Hubungan lama penggunaan dan jarak pandang gadget dengan ketajaman penglihatan pada anak sekolah dasar kelas 2 dan 3 di SDN 027 Kota Samarinda. Samarinda: Sekolah Tinggi Ilmu Kesehatan Muhammadiyah; 2017.

18. Hutami WD, Wulandari PA. Prevalensi penurunan tajam penglihatan pada siswa kelas 3-6 Sekolah Dasar Negeri 1 Manggis, Karangasem Bali tahun 2014. ISM. 2016;6(1):102-110

19. Mowatt L, Gordon C, Santosh ABR, Jones T. Computer vision syndrome and ergonomic practices among undergraduate university students. Jamaica: The University of the West Indies; 2017.

20. Navarona ANI. Hubungan antara praktek unsafe action dalam penggunaan gadget dengan keluhan subyektif gangguan kesehatan mata pada murid Sekolah Dasar Islam Tunas Harapan tahun 2016. Semarang: Universitas Dian Nuswantoro; 2016.

21. Leat SJ. Paediatric assessment. In: Rosenfield M, Logan N, editors. Optometry Science Techniques and Clinical Management (2nd ed). New York: Elsevier, 2009.

22. Thilakarathne MMSV, Udara HMM, Thucyanthan B, Ranasinghe $\mathbf{P}$. Prolonged computer use and its effects on vision among undergraduates in University of Colombo, school of computing. Sri Lanka: University of Colombo; 2017.

23. Kim DJ, Lim CY, Gu N, Park CY. Visual fatigue induced by viewing a tablet computer with a high-resolution display. Korea: Dongguk University Ilsan Hospital; 2017.

24. Dhungel D, Shrestha GS. Visual symptoms associated with refractive errors among Thangka artists of Kathmandu valley. Nepal: Institue of Medicine, Tribhuvan University; 2017. 